\title{
Prognostic value of histological type in stage IV ovarian carcinoma: a retrospective analysis of 223 patients
}

\author{
M Mizuno*,1, H Kajiyama ${ }^{1}$, K Shibata ${ }^{1}, \mathrm{~K} \mathrm{Mizuno}^{2}$, M Kawai ${ }^{3}, \mathrm{~T} \mathrm{Nagasaka}^{4}$ and F Kikkawa ${ }^{1}$ \\ ${ }^{1}$ Department of Obstetrics and Gynecology, Nagoya University Graduate School of Medicine, 65 Tsuruma-cho, Showa-ku, Nagoya \\ 466-8550, Japan; ${ }^{2}$ Department of Obstetrics and Gynecology, Nagoya First Red Cross Hospital, 3-35 Michishita, Nakamuraku-ku, \\ Nagoya 453-8511, Japan; ${ }^{3}$ Department of Obstetrics and Gynecology, Toyohashi Municipal Hospital, 50 Aotake-cho, Toyohashi \\ 441-8570, Japan and ${ }^{4}$ Nagoya University School of Health Science, 1-20 Dikou-minami, Higashi-ku, Nagoya 461-0047, Japan
}

Background: Patients with FIGO stage IV epithelial ovarian carcinoma have a poor but non-uniform prognosis. This study aimed to compare the survival of patients with serous or endometrioid tumours $(\mathrm{S} / \mathrm{E})$ and clear cell or mucinous tumours (non-S/E).

Methods: Data for 223 patients who underwent surgery between 1987 and 2010 and were diagnosed by centralized pathology review and were retrospectively analysed. The patients included 169 with S/E tumours and 54 with non-S/E tumours.

Results: The median overall survivals (OSs) of the S/E and non-S/E groups were 3.1 and 0.9 years, respectively $(P<0.001)$. Six patients (2.7\%), all with non-S/E tumours, died within 6 weeks after the initial surgery. Multivariate OS analysis revealed that performance status, residual tumor, metastatic sites, no debulking surgery, and non-S/E tumours were independent poor prognostic factors. For patients with non-S/E tumours, prognosis was more favourable for single-organ metastasis, except for liver or distant lymph nodes, no residual tumor, and resection of metastasis (median OS: 4.1, 4.6, and 2.6 years, respectively).

Conclusions: In stage IV ovarian carcinoma, non-S/E tumours are associated with a significantly poorer prognosis and higher rates of early mortality compared to S/E tumours. Therefore, careful management and development of new strategies are required.

Epithelial ovarian cancer (EOC) is one of the most lethal gynaecological malignancies (Brun et al, 2000; Jemal et al, 2007). In fact, $\sim 15 \%$ of patients with EOC are diagnosed as International Federation of Gynaecology and Obstetrics (FIGO) stage IV disease. In previous studies, the median overall survival (OS) of patients with stage IV EOC was 15-29 months, with an estimated 5-year OS of 20\% (Bristow et al, 1999; Akahira et al, 2001; Winter et al, 2008; Trope et al, 2012). Many authors have reported that a combination of aggressive cytoreductive surgery and platinumbased chemotherapy improves survival and delays recurrence in patients with advanced EOC (Trimble et al, 2000; Bristow et al, 2002; Crawford et al, 2005). Previous research has shown that performance status (PS), as categorised by the Eastern Cooperative Oncology Group (ECOG) or World Health Organization (WHO), and the presence of residual tumours are well-known prognostic factors for OS of patients with stage IV cancer (Goodman et al, 1992;
Curtin et al, 1997; Bristow et al, 1999; Trope et al, 2012). Some authors have reported that radical debulking surgery (DS) or microscopic cytoreduction are the most important factors affecting survival, even for patients with stage IV disease (Bristow et al, 1999; Winter et al, 2008; Luyckx et al, 2012).

The survival of patients with stage IV EOC remains poor and is not uniform owing to various metastatic patterns, PS, or histological characteristics. The histologic types of EOC are diagnosed based on the morphological criteria (1971; Tavassoli, 2003), and chemosensitivity and biological characteristics vary among histological types (Baak et al, 1986). In particular, serous tumours, one of the most advanced forms of EOC, are highly chemosensitive, which appears to affect survival results. A number of reports comparing clear cell or mucinous tumours to other epithelial tumours have indicated that these tumours have a worse prognosis than others in advanced stages (Sugiyama et al, 2000;

*Correspondence: Dr M Mizuno; E-mail: mizunomizuno@med.nagoya-u.ac.jp

Received 31 October 2014; revised 23 January 2015; accepted 16 February 2015; published online 24 March 2015

(c) 2015 Cancer Research UK. All rights reserved 0007-0920/15 
Hess et al, 2004). However, there are few detailed analyses concerning the survival of patients with clear cell or mucinous tumours because few of these tumours are stage IV.

The aim of our study was to analyse both long-term survival and early mortality of patients with stage IV EOC by comparing serous or endometrioid tumours (S/E) with clear cell, mucinous, or other tumours (non-S/E).

\section{METHODS}

Between January 1987 and December 2010, 2385 patients with EOC were registered and treated by the Tokai Ovarian Tumor Study Group of Nagoya University Hospital and affiliated hospitals. Approval from the Ethics Committee of our hospital was obtained before study registration. The patients were enroled in this study based on medical data and the surgical specimens from affiliated institutions. The specimens were returned after a central pathological review. The review was performed by one fixed pathologist specializing in gynaecologic tumours. Since 2012, the central pathological review system had consisted of two fixed pathologists and one gynaecologic oncology specialist. When there was a different diagnosis between each hospital and the central review, we informed each institution of the results with detailed comments. If it was necessary to distinguish the histological type, we added the findings from the immunochemistry staining. When it was difficult to diagnose the histology in residual tumours because of the prior chemotherapeutic effect, it was identified as 'adenocarcinoma' or 'no residual cancer'. These cases were excluded from this study. A total of $244(10.2 \%)$ of the 2385 patients were diagnosed with stage IV cancer by a central pathological review system. Of the 244 patients, those who had not undergone surgery and those lost to follow-up immediately after the initial treatment were excluded. Prognostic data from the remaining 223 patients were retrospectively evaluated by dividing the patients into two groups: 169 patients (75.7\%) were in the S/E group, including 144 (64.5\%) with serous tumours, and 54 patients $(24.2 \%)$ were in the non-S/E group, including 23 (10.5\%) with clear cell tumours, $16(7.2 \%)$ with mucinous tumours, 7 (3.1\%) with undifferentiated tumours, and 5 (2.2\%) with unclassified tumours. Pathological staging was assessed according to the 1988 FIGO criteria (Rio de Janeiro, Brazil), TNM Classification of Malignant Tumours by the Union for International Cancer Control (UICC), and all tumours were histologically classified according to the WHO classification. Pure-type clear cell adenocarcinoma was pathologically diagnosed if typical clear cytoplasm or hobnail cells growing in a papillary, solid, or tubular-cystic pattern appeared in more than $90 \%$ of all pathological specimens.

DS consisted of total hysterectomy, bilateral salpingo-oophorectomy, and total/partial omentectomy with/without resection of the metastatic tumor or pelvic and para-aortic lymphadenectomy. Non-DS was defined as surgery other than DS, namely exploratory laparotomy or salpingo-oophorectomy for the diagnosis of cancer. Patients in the non-DS group had not undergone secondary DS because of progression of the disease. Interval DS (IDS) included DS after several cycles of neoadjuvant chemotherapy (NAC) with/ without primary incomplete surgery. All 70 patients who had NAC without primary surgery had positive cytology of cancerous ascites/ pleural effusion or carcinoma by biopsy of metastatic sites. Of the 70 patients, the presence of peritoneal dissemination beyond the pelvis was also examined by imaging analysis, such as computed tomography. The pathological diagnosis in these patients was performed using IDS specimens. The residual tumor was defined as the maximal tumor diameter at the time of surgery.

Patients who received adjuvant chemotherapy were divided into two groups, one receiving taxane-platinum therapy (TP) and the other receiving platinum-based therapy. The TP group consisted of 122 patients who received paclitaxel $\left(175-180 \mathrm{mg} \mathrm{m}^{-2}\right)$ plus carboplatin (AUC 5-6), 4 who received docetaxel $\left(70 \mathrm{mg} \mathrm{m}^{-2}\right.$ ) plus carboplatin (AUC 5-6), and 2 others. Other platinum-based therapies were given to 91 patients, including 46 who received cyclophosphamide $\left(300 \mathrm{mg} \mathrm{m}^{-2}\right)$ plus cisplatin $\left(70 \mathrm{mg} \mathrm{m}^{-2}\right)$ with/ without adriamycin $\left(30 \mathrm{mg} \mathrm{m}^{-2}\right) ; 17$ who received bleomycin $\left(12 \mathrm{mg} \mathrm{m}^{-2}\right)$, vinblastine $\left(6 \mathrm{mg} \mathrm{m}^{-2}\right)$, and cisplatin $\left(70 \mathrm{mg} \mathrm{m}^{-2}\right)$; 18 who received carboplatin $\left(300 \mathrm{mg} \mathrm{m}^{-2}\right)$ plus cisplatin (70 $\left.\mathrm{mg} \mathrm{m}^{-2}\right)$; and 12 others. Further details concerning the employed chemotherapy regimens have been documented in our previous report (Mizuno et al, 2006). Most responses to treatment in the recent cases were evaluated according to the Response Evolution Criteria in Solid Tumours (RECIST) guidelines. However, it was difficult to adapt the RECIST to the past cases; therefore, we defined this case, in which there were no disease findings based on imaging and tumor markers after initial treatment, as a complete response (CR); another case was identified as non-CR.

Survival was measured from the date of diagnosis until the date of death or of the final follow-up visit. OS curves were calculated using the Kaplan-Meier method, and significance was determined using log-rank tests. Multivariate analysis was performed using the Cox proportional hazards model to evaluate the effects of independent factors on survival. Categorical data, which were analysed using the chi-squared test or Fisher's exact test, were used for comparisons of our data, and $P$-values $<0.05$ were considered statistically significant. All statistical analyses were performed using the IBM SPSS software package for Windows, version 21 (Armonk, NY, USA).

\section{RESULTS}

Patient characteristics. The characteristics of the patients with S/E and non-S/E tumours are summarised in Table 1 . The median age at the time of diagnosis for patients with S/E tumours was 56.8 years, with a range of 30-79, and the median age at the time of diagnosis for patients with non-S/E tumours was 54 years, with a range of $18-78(P=0.309)$. The rate of IDS was significantly lower in the non-S/E group than in the S/E group (14 vs $46.1 \%$, respectively). There were no significant differences in the rate of TP chemotherapy $v s$ other platinum-based regimens that were used as first-line chemotherapy $(P=0.468)$. However, the four patients who had not undergone post-surgery chemotherapy because of complications belonged to the non-S/E group. The mean number of cycles of first-line chemotherapy was significantly lower for the non-S/E group than for the S/E group (5.1 cycles $v s$ 6.98 cycles, respectively; $P<0.001)$. The data on the metastatic sites and on the resection of the metastatic sites for all cases are shown in Supplementary Table 1-2. Of the 31 cases involving lymph nodes, $90.3 \%$ (28 out of 31 ) exhibited metastasis to the supradiaphragmatic lymph nodes. Forty-three patients had metastatic involvement of other single organs, including 12 lung, 10 umbilicus, 9 spleen, 5 breast, 3 bone, and 4 others (the data are shown in Supplementary Table 1). In terms of resection of metastatic sites, bowel surgery was performed in 22 patients, liver tumor extraction was performed in 5 patients, neck dissection was performed in 5 patients, splenectomy was performed in 4 patients, and pulmonary tumor extraction was performed in 3 patients (the data are shown in Supplementary Table 2).

OS. The median OS times of the S/E and non-S/E groups were 3.1 (95\% confidence interval (CI), 1.9-3.2) and 0.9 (95\% CI, 0.6-1.3) years, respectively $(P<0.001)$, and the 5 -year OSs for these groups were 31 and 16\%, respectively. The median OS according to histological type based on univariate analysis is shown in Table 2. The prognosis of the non-S/E group was significantly worse in relation to many variables, and the median OS for this group was 
Table 1. Patient characteristics

\begin{tabular}{|c|c|c|c|c|}
\hline \multirow[b]{2}{*}{ Variables } & \multicolumn{4}{|c|}{ Number of patients (\%) } \\
\hline & Total & S/E group ${ }^{a}$ & $\begin{array}{l}\text { non-S/E } \\
\text { group }\end{array}$ & $P$-value \\
\hline \multicolumn{5}{|l|}{ Age (years) } \\
\hline $\begin{array}{l}<60 \\
\geqslant 60\end{array}$ & $\begin{array}{r}146 \\
77\end{array}$ & $\begin{array}{r}109(64.5) \\
60(35.5)\end{array}$ & $\begin{array}{l}37(68.5) \\
17(31.5)\end{array}$ & 0.626 \\
\hline \multicolumn{5}{|l|}{ Performance status } \\
\hline $\begin{array}{l}0-1 \\
2-4\end{array}$ & $\begin{array}{r}166 \\
53\end{array}$ & $\begin{array}{r}134(79.3) \\
36(21.3)\end{array}$ & $\begin{array}{l}32(59.3) \\
17(31.5)\end{array}$ & 0.096 \\
\hline \multicolumn{5}{|l|}{ Metastatic site } \\
\hline $\begin{array}{l}\text { Pleural effusion } \\
\text { Liver } \\
\text { Lymph nodes } \\
\text { Other single organ } \\
\text { Multiple organs }\end{array}$ & $\begin{array}{l}89 \\
31 \\
31 \\
43 \\
29\end{array}$ & $\begin{array}{l}68(40.2) \\
24(14.2) \\
29(17.2) \\
30(17.8) \\
18(10.7)\end{array}$ & $\begin{aligned} 21 & (38.9) \\
7 & (13.0) \\
2 & (3.7) \\
11 & (20.4) \\
9 & (16.9)\end{aligned}$ & 0.128 \\
\hline \multicolumn{5}{|l|}{ Stage $^{b}$} \\
\hline $\begin{array}{l}\text { pT1 } \\
\text { pT2 } \\
\text { pT3 }\end{array}$ & $\begin{array}{r}11 \\
18 \\
122 \\
\end{array}$ & $\begin{array}{c}7(6.7) \\
12(11.3) \\
87(82.0)\end{array}$ & $\begin{array}{c}4(8.8) \\
6(13.3) \\
35(77.7)\end{array}$ & 0.816 \\
\hline \multicolumn{5}{|c|}{ Peritoneal dissemination beyond pelvis } \\
\hline $\begin{array}{l}\text { Yes } \\
\text { No }\end{array}$ & $\begin{array}{r}176 \\
45 \\
\end{array}$ & $\begin{array}{r}138(81.7) \\
30(17.8) \\
\end{array}$ & $\begin{array}{l}38(70.4) \\
15(27.8)\end{array}$ & 0.076 \\
\hline \multicolumn{5}{|l|}{ Surgery } \\
\hline $\begin{array}{l}\text { Primary debulking surgery } \\
\text { Interval debulking surgery } \\
\text { Incomplete surgeryc }\end{array}$ & $\begin{array}{l}91 \\
86 \\
46 \\
\end{array}$ & $\begin{array}{l}65(38.5) \\
78(46.2) \\
26(15.4) \\
\end{array}$ & $\begin{array}{r}26(48.1) \\
8(14.8) \\
20(37.0) \\
\end{array}$ & $<0.001$ \\
\hline \multicolumn{5}{|l|}{ Lymphadenectomy $^{d}$} \\
\hline $\begin{array}{l}\text { Yes } \\
\text { No }\end{array}$ & $\begin{array}{r}65 \\
112\end{array}$ & $\begin{array}{l}52(36.4) \\
91(63.6)\end{array}$ & $\begin{array}{l}13(39.4) \\
21(63.3)\end{array}$ & 0.883 \\
\hline \multicolumn{5}{|c|}{ Resection of metastatic sites ${ }^{d}$} \\
\hline $\begin{array}{l}\text { Yes } \\
\text { No }\end{array}$ & $\begin{array}{r}40 \\
137 \\
\end{array}$ & $\begin{array}{r}33(23.1) \\
110(76.9)\end{array}$ & $\begin{array}{r}7(21.2) \\
28(84.8)\end{array}$ & 0.696 \\
\hline \multicolumn{5}{|l|}{ Residual tumor } \\
\hline $\begin{array}{l}\text { No } \\
<1 \mathrm{~cm} \\
\geqslant 1 \mathrm{~cm}\end{array}$ & $\begin{array}{r}51 \\
21 \\
151\end{array}$ & $\begin{array}{r}42(24.8) \\
19(11.2) \\
108(63.9)\end{array}$ & $\begin{array}{c}9(16.7) \\
2(3.7) \\
43(79.6)\end{array}$ & 0.076 \\
\hline \multicolumn{5}{|l|}{ Regimen of first line } \\
\hline $\begin{array}{l}\text { Taxane-platinum } \\
\text { Other platinum based }\end{array}$ & $\begin{array}{r}128 \\
91\end{array}$ & $\begin{array}{r}101(59.8) \\
68(40.2)\end{array}$ & $\begin{array}{l}27(50.0) \\
23(42.6)\end{array}$ & 0.468 \\
\hline \multicolumn{5}{|c|}{ Cycles of first-line chemotherapy } \\
\hline Mean (range) & & $6.98(1-19)$ & $5.1(1-10)$ & $<0.001$ \\
\hline \multicolumn{5}{|c|}{ Serum CA125 (IU ml $\left.{ }^{-1}\right)$} \\
\hline Median (range) & & $1790(8-18290)$ & $280(32-9700)$ & $<0.001$ \\
\hline \multicolumn{5}{|l|}{ Ascites (ml) } \\
\hline $\begin{array}{l}<1000 \\
>1000 \\
\text { Unknown }\end{array}$ & $\begin{array}{r}123 \\
81 \\
15 \\
\end{array}$ & $\begin{array}{l}92(54.4) \\
63(37.3) \\
14(8.3) \\
\end{array}$ & $\begin{array}{c}32(59.3) \\
21(38.9) \\
1(1.9)\end{array}$ & 0.268 \\
\hline \multicolumn{5}{|c|}{ 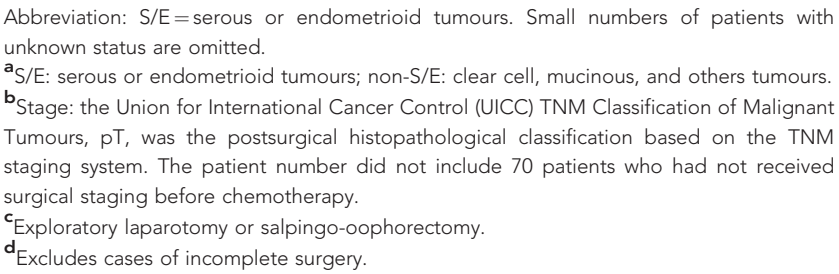 } \\
\hline
\end{tabular}

particularly low for patients who had metastases to multiple organs (OS 0.26 years), $\mathrm{PS}>2$ ( 0.5 years), and $\geqslant 1000 \mathrm{ml}$ ascites volume (0.5 years). However, the survival of patients with non-S/E tumours was similar to that of those with S/E tumours according to each of the following factors: metastasis to other single organs, which was defined as metastasis other than pleural effusion or to the liver or distant lymph nodes (median OS: 4.1 vs 3.9 years, $P=0.871) ;<1 \mathrm{~cm}$ residual tumor (4.6 vs 4.2, $P=0.258$ ); and resection of metastatic sites ( 4.2 vs 2.6 years, $P=0.258)$. When analysing patients based on metastatic site, there were significant
Table 2. Survival analysis according to histological types

\begin{tabular}{|c|c|c|c|c|}
\hline \multirow{2}{*}{ Variables } & \multicolumn{4}{|c|}{$\begin{array}{l}\text { Median overall } \\
\text { survival (years) }\end{array}$} \\
\hline & $\begin{array}{c}\text { Total } \\
\text { number }\end{array}$ & $\begin{array}{c}\text { S-E } \\
\text { group }^{a}\end{array}$ & $\begin{array}{c}\text { Non-S/E } \\
\text { group }\end{array}$ & $P$-value \\
\hline \multicolumn{5}{|l|}{ Age (years) } \\
\hline$<60$ & 146 & 3.4 & 1.1 & $<0.001$ \\
\hline$\geqslant 60$ & 77 & 3.1 & 0.8 & 0.010 \\
\hline \multicolumn{5}{|l|}{ Performance status } \\
\hline $0-1$ & 166 & 3.3 & 1.0 & $<0.001$ \\
\hline $2-4$ & 53 & 2.1 & 0.5 & 0.027 \\
\hline \multicolumn{5}{|l|}{ Metastatic site } \\
\hline Pleural effusion & 89 & 3.4 & 0.7 & $<0.001$ \\
\hline Liver or distant lymph nodes & 62 & 2.6 & 1.1 & 0.004 \\
\hline Other single organs & 43 & 3.9 & 4.1 & 0.871 \\
\hline Multiple organs & 29 & 1.8 & 0.26 & 0.009 \\
\hline \multicolumn{5}{|l|}{ Stage $^{b}$} \\
\hline pT1 & 11 & 3.4 & $(75 \%)$ & 0.35 \\
\hline рT2 & 18 & 8.1 & 0.7 & 0.084 \\
\hline рT3 & 122 & 2.4 & 0.6 & $<0.001$ \\
\hline
\end{tabular}

Peritoneal dissemination beyond pelvis

\begin{tabular}{|c|c|c|c|c|}
\hline $\begin{array}{l}\text { Yes } \\
\text { No }\end{array}$ & $\begin{array}{r}176 \\
45\end{array}$ & $\begin{array}{l}3.1 \\
3.3\end{array}$ & $\begin{array}{l}0.7 \\
1.4\end{array}$ & $\begin{array}{r}<0.001 \\
0.377\end{array}$ \\
\hline \multicolumn{5}{|l|}{ Surgery } \\
\hline Primary debulking surgery & 91 & 3.7 & 1.4 & 0.195 \\
\hline Interval debulking surgery & 86 & 3.6 & 1.1 & 0.008 \\
\hline Incomplete surgery ${ }^{c}$ & 46 & 1.4 & 0.6 & $<0.001$ \\
\hline \multicolumn{5}{|l|}{ Lymphadenectomy $^{d}$} \\
\hline Yes & 65 & 2.8 & 1.1 & 0.459 \\
\hline No & 112 & 3.8 & 1.4 & 0.005 \\
\hline \multicolumn{5}{|c|}{ Resection of metastatic sites $^{d}$} \\
\hline Yes & 40 & 4.2 & 2.6 & 0.258 \\
\hline No & 137 & 3.4 & 1.3 & 0.023 \\
\hline \multicolumn{5}{|l|}{ Residual tumor } \\
\hline No & 51 & 4.1 & 4.6 & 0.581 \\
\hline$<1 \mathrm{~cm}$ & 21 & 3.9 & 1.4 & 0.046 \\
\hline$\geqslant 1 \mathrm{~cm}$ & 108 & 2.4 & 0.9 & $<0.001$ \\
\hline \multicolumn{5}{|l|}{ Regimen of first line } \\
\hline Taxane-platinum & 128 & 3.6 & 1.4 & 0.033 \\
\hline Other platinum based & 91 & 2.5 & 0.7 & $<0.001$ \\
\hline \multicolumn{5}{|l|}{ Serum CA125 (IU ml $\left.{ }^{-1}\right)$} \\
\hline$<1000$ & 112 & 2.2 & 0.9 & 0.025 \\
\hline$\geqslant 1000$ & 111 & 3.7 & 0.9 & $<0.001$ \\
\hline \multicolumn{5}{|l|}{ Ascites (ml) } \\
\hline$<1000$ & 124 & 3.4 & 1.1 & 0.011 \\
\hline$\geqslant 1000$ & 84 & 2.6 & 0.5 & $<0.001$ \\
\hline \multicolumn{5}{|c|}{$\begin{array}{l}\text { Abbreviation: } S / E=\text { serous or endometrioid tumours. Small numbers of patients with } \\
\text { unknown status are omitted. } \\
a_{S} \text { /E: serous or endometrioid tumours; non-S/E: clear cell, mucinous, and others tumours. } \\
b_{\text {Stage: the Union for International Cancer Control (UICC) TNM Classification of Malignant }} \\
\text { Tumours. Patient's number did not included } 70 \text { patients who did not receive surgery before } \\
\text { neoadjuvant chemotherapy. 5-year OS rate on pT1 in non-S/E group was } 75 \% \text {. } \\
c_{\text {Exploratory laparotomy or salpingo-oophorectomy. }} \\
d_{\text {Excludes cases of incomplete surgery. }}\end{array}$} \\
\hline
\end{tabular}

differences in OS for those in the non-S/E group who had metastasis to other single organs $v$ p pleural effusion $(P=0.038)$ and for those who had metastasis to other single organs $v s$ to multiple organs $(P=0.020)$, but there were no differences in OS in the $S / E$ group based on metastatic site. Furthermore, the prognosis in each metastatic site was analysed for patients with residual tumor compared with patients without residual tumor (Figure 1). In the $\mathrm{S} / \mathrm{E}$ group, there was a significant difference in other single organs between patients with residual tumor and those without residual tumor $(P=0.020$, Figure $1 \mathrm{~A})$, but there was no difference in 
pleural effusion (Figure 1B). In the non-S/E group, although there was no significant difference in each metastatic site, the prognosis of other single organs was more favourable for no residual tumor (5-year OS: residual $(+)$, 32\% vs residual $(-)$, $72 \%, P=0.549$, Figure 1A).

The median OSs for both TP and other platinum-based chemotherapy regimens were statistically lower in the non-S/E group than in the S/E group. However, in the non-S/E group, the prognosis of patients who received TP chemotherapy was significantly more favourable than that of patients who received other platinum-based regimens (median OS: 1.4 vs 0.7 years, respectively; $P=0.017$; Figure $2 \mathrm{~A}$ and $\mathrm{B}$ ).

Multivariate analysis was performed to further assess the factors, and these results are shown in Table 3 . The analysis indicated that age, PS, metastatic pattern, surgery, residual tumor, and histological type were all factors that predicted worse survival of patients with stage IV EOC. The presence of multiple metastatic sites, $>2 \mathrm{~cm}$ residual tumor, and non-S/E tumours were found to be the most powerful predictors of prognosis.

Recurrence-free survival. In terms of the response to initial treatment, CR was achieved by $73 \%$ of the $169 \mathrm{~S} / \mathrm{E}$ patients and by $31.4 \%$ of the 54 non-S/E patients and non-CR occurred in $37 \%$ of the $\mathrm{S} / \mathrm{E}$ and $68.6 \%$ of the non-S/E patients. The proportion of patients in the non-S/E group with CR was significantly lower than that of the $\mathrm{S} / \mathrm{E}$ group $(P<0.001)$, but there was no significant difference in the $\mathrm{CR}$ survival curve, as shown in Figure $3 \mathrm{~A}$ and $\mathrm{B}$ (median OS S/E 3.9 vs non-S/E 5.6 years, $P=0.391$ ). Disease relapsed in $119(83.8 \%)$ of 142 patients with an initial CR. In these patients, the interval between effect assessment and recurrence
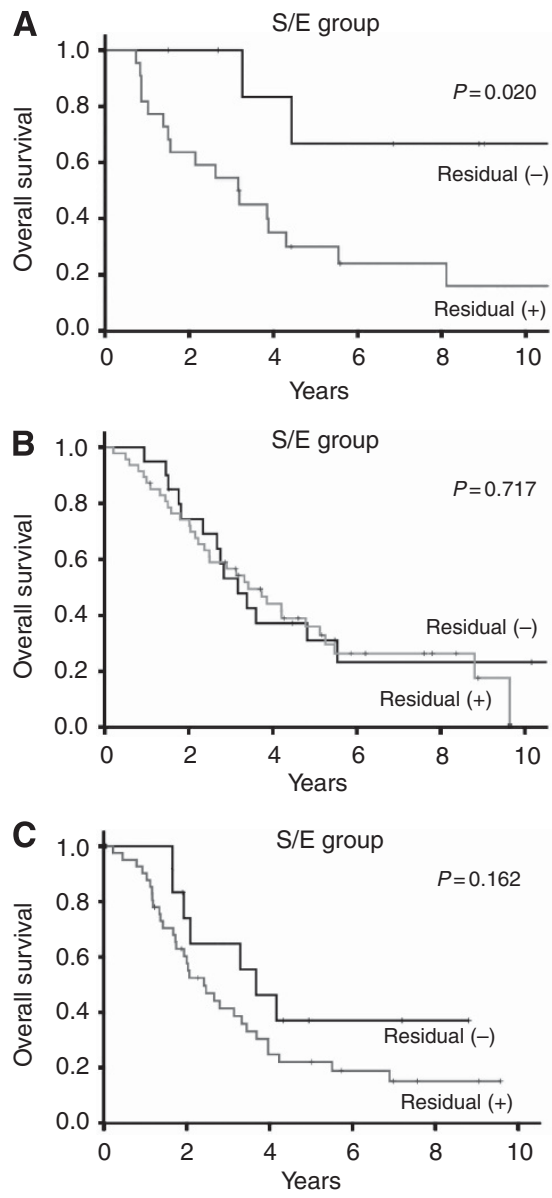

ranged from 1 month to 6.4 years, and there was no difference in the median recurrence-free survival between the S/E and non-S/E groups (1.5 vs 1.4 years, respectively; $P=0.74$ ).

Early death and treatment-related mortality. Table 4 presents data for 14 patients with early death, defined as death within 3 months after primary surgery. The rate of early death was higher in the non-S/E group than in the S/E group (78.5 vs $21.4 \%$, respectively; $P<0.001)$. Death within 6 weeks occurred in 6 $(2.7 \%)$ patients in the non-S/E group. With regard to perioperative-related mortality, one patient had a cerebral infarction immediately after surgery, and another patient who had undergone IDS died owing to a pulmonary embolism following surgery (not shown in Table 4).

\section{DISCUSSION}

The present study retrospectively analysed the largest series of patients with stage IV EOC by comparing histological tumor types. Univariate and multivariate analyses revealed that non-S/E tumours were associated with a significantly worse prognosis and higher mortality rates compared with S/E tumours. However, our data demonstrated that patients with non-S/E tumours had OSs similar to those of patients with $\mathrm{S} / \mathrm{E}$ tumours in regards to no residual tumor and single metastatic site, except for liver and lymph nodes.

As described in the Introduction, the 5-year OS of patients with stage IV EOC is 20\% (Bristow et al, 1999; Akahira et al, 2001; Winter et al, 2008; Trope et al, 2012); however, our results indicated a slightly better OS for these patients, i.e., a 5-year OS of
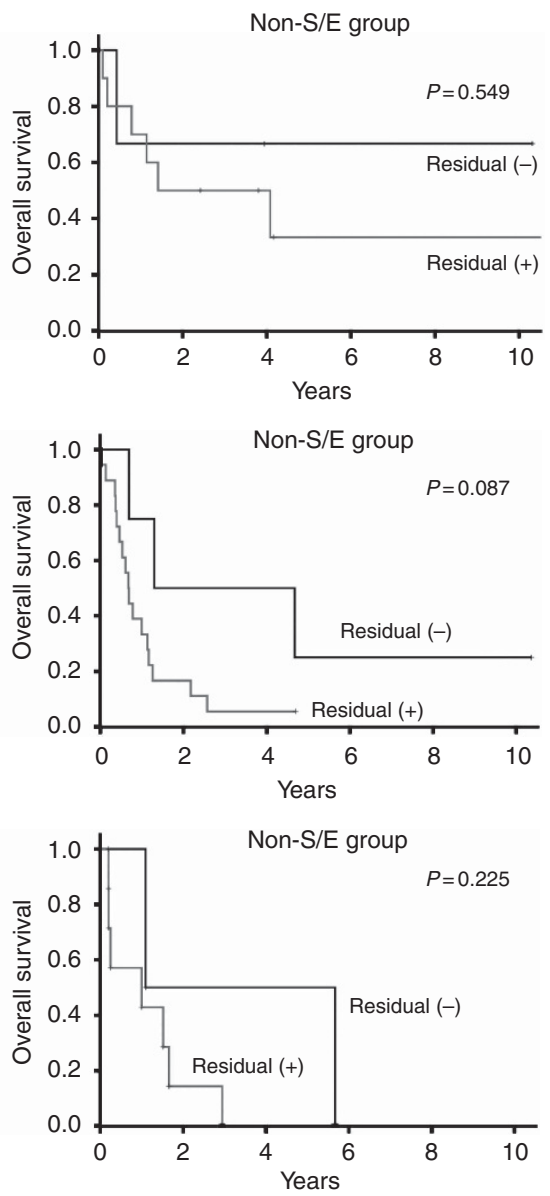

Figure 1. Overall survival curves according to the metastatic sites for stage IV patients either with residual tumor vs without residual tumor in each group; serous or endometrioid tumours (S/E group) and clear cell, mucinous, and other tumours (non-S/E group). (A) Other single organ, (B) pleural effusion, and (C) liver and lymph nodes. 

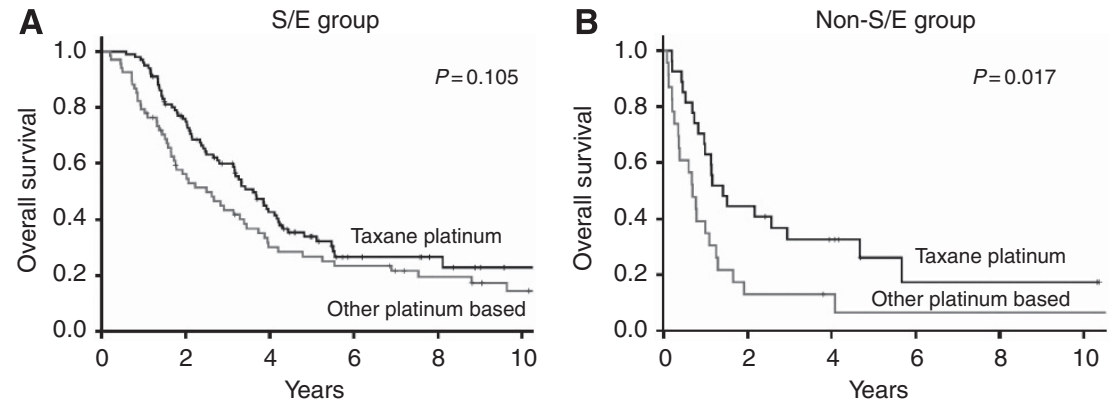

Figure 2. Overall survival curves according to chemotherapy regimen for patients with stage IV ovarian carcinoma. (A) S/E group, serous or endometrioid tumours; (B) non-S/E group, clear cell, mucinous, and others tumours.

\begin{tabular}{|c|c|c|c|}
\hline Variables & Hazard ratio & 95\% Confidence interval & $P$-value \\
\hline \multicolumn{4}{|l|}{ Performance states } \\
\hline $0-1$ vs $2-4$ & 1.730 & $1.188-2.520$ & 0.004 \\
\hline \multicolumn{4}{|l|}{ Metastatic site } \\
\hline Other single organ ${ }^{a}$ vs pleural effusion & 1.674 & $1.038-2.701$ & 0.035 \\
\hline Other single organ vs liver/lymph node & 1.965 & $1.183-3.263$ & 0.009 \\
\hline Other single organ vs plural organs & 2.697 & $1.502-4.845$ & 0.001 \\
\hline \multicolumn{4}{|l|}{ Surgery } \\
\hline PDS vs IDS ${ }^{b}$ & 1.038 & $0.689-1.564$ & 0.857 \\
\hline PDS vs incomplete surgery ${ }^{c}$ & 2.377 & $1.536-3.679$ & $<0.001$ \\
\hline \multicolumn{4}{|l|}{ Residual tumor } \\
\hline No residual vs $<1 \mathrm{~cm}$ & 1.889 & $1.047-3.411$ & 0.035 \\
\hline No residual $v s \geqslant 1 \mathrm{~cm}$ & 2.008 & $1.235-3.265$ & 0.005 \\
\hline \multicolumn{4}{|l|}{ Histological type } \\
\hline S/E group vs non-S/E group ${ }^{c}$ & 2.416 & $1.631-3.580$ & $<0.001$ \\
\hline
\end{tabular}

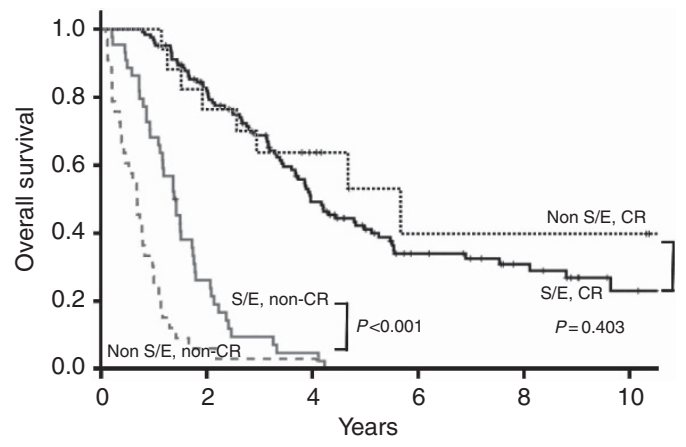

Figure 3. Overall survival curves according to the initial treatment response in patients with stage IV ovarian carcinoma. S/E group, serous or endometrioid tumours; non-S/E group: clear cell, mucinous, and other tumours; $\mathrm{CR}=$ complete response.

27.9\% and a median OS of 30.8 months. Regarding histological type, many authors have demonstrated that clear cell or mucinous tumours have a significantly worse prognosis than other histologic types of stage IV EOC (Chan et al, 2008; Winter et al, 2008; Wimberger et al, 2010; Elstrand et al, 2012; Trope et al, 2012); the reported median OS ranges for serous tumours and clear cell tumours with or without mucinous tumor are 18.2-29.3 months and 6-14.2 months, respectively. Some multivariate analyses have demonstrated that clear cell/mucinous tumours are an independent prognostic factor (serous vs clear cell/mucinous tumours: hazard ratio (HR) 2.6, 95\% CI 1.5-4.5, P=0.001; Winter et al, 2008; Elstrand et al, 2012; Trope et al, 2012). However, in these reports, the number of patients with these tumours was very small. Approximately $70 \%$ of patients with advanced-stage EOC have serous adenocarcinoma (McGuire et al, 1996; Chan et al, 2008), and both mucinous and clear cell adenocarcinomas are rare diseases. Previous research on stage IV EOC has demonstrated that $\sim 2 \%(1.4-3 \%)$ of patients have clear cell tumours and that $4 \%$ (3.5-5.3\%) have mucinous or clear cell tumours (Winter et al, 2008; Bamias et al, 2010; Rauh-Hain et al, 2012; Trope et al, 2012). Although Chan et al (2008) and other authors have reported that patients with clear cell tumours are more likely to be Asian (Mizuno et al, 2006; Chan et al, 2008), only a few reports have analysed stage IV EOC populations with a high percentage of clear cell (Akahira et al, 2001) or mucinous tumours (Wimberger et al, 2010). In this study, we analysed the prognostic factors of this disease by comparing the non-S/E group, which comprised $10.3 \%$ clear cell tumours, 7.2\% mucinous tumours, and 3.1\% undifferentiated tumours, with the S/E group, which included 64\% serous tumours. By both univariate and multivariate analyses, the prognosis of the non-S/E group, which included a high percentage of clear cell tumours, was worse than that of the S/E group (HR 2.6, $95 \%$ CI $1.5-4.5, P=0.001$ ), as expected. In this study, we analysed clear cell, mucinous, and the other tumours as a group because there were no significant differences in the median OS of these histological types in the non-S/E group (clear tumor, 8.8 months; mucinous tumor, 11.3 months; and other tumours, 13.2 months).

Of the 14 patients who died within 3 months after primary surgery, 50\% underwent primary DS (PDS) and 50\% underwent incomplete surgery, as shown in Table 4. Eight (57.1\%) of the patients with early death had PS of $0-1$, and $6(42.8 \%)$ had PS $>2$. Notably, among 14 patients with early death, a significantly higher 


\begin{tabular}{|c|c|c|c|c|c|c|c|c|c|c|}
\hline \multirow[b]{2}{*}{ Case } & \multirow[b]{2}{*}{$\begin{array}{c}\text { Age } \\
\text { (years) }\end{array}$} & \multirow[b]{2}{*}{$\begin{array}{l}\text { Histological } \\
\text { type }\end{array}$} & \multirow[b]{2}{*}{ Surgery } & \multirow[b]{2}{*}{$\begin{array}{l}\text { Metastatic } \\
\text { sites }\end{array}$} & \multirow[b]{2}{*}{ Ascites } & \multirow[b]{2}{*}{$\begin{array}{c}\text { Residual } \\
\text { tumor }\end{array}$} & \multicolumn{4}{|c|}{$\begin{array}{c}\text { Overall survival time } \\
\text { (months) }\end{array}$} \\
\hline & & & & & & & $\begin{array}{l}\text { Chemo- } \\
\text { therapy }\end{array}$ & \begin{tabular}{c|} 
Post \\
surgery
\end{tabular} & $\begin{array}{c}\text { Post chemo- } \\
\text { therapy }\end{array}$ & Outcome \\
\hline 1 & 47 & Clear cell & Salpingo-oophorectomy & Plural effusion & $>1000 \mathrm{ml}$ & $>5 \mathrm{~cm}$ & None & 0.3 & - & $\mathrm{Cl}$ \\
\hline 2 & 70 & Clear cell & Exploratory laparotomy & $\begin{array}{l}\text { Liver } \\
\text { Pleural effusion }\end{array}$ & $<100 \mathrm{ml}$ & $1-2 \mathrm{~cm}$ & 1 cycle & 1.0 & 0.5 & DOD \\
\hline 3 & 49 & Mucinous & Salpingo-oophorectomy & $\begin{array}{l}\text { Lung } \\
\text { Vagina }\end{array}$ & $500-1000 \mathrm{ml}$ & $>5 \mathrm{~cm}$ & None & 1.2 & - & DOD \\
\hline 4 & 68 & Clear cell & $\begin{array}{l}\mathrm{DS}^{\mathrm{a}}+\text { lymphadenectomy, } \\
\text { bowel surgery }\end{array}$ & $\begin{array}{l}\text { Liver } \\
\text { Lymph nodes }\end{array}$ & $>1000 \mathrm{ml}$ & $>5 \mathrm{~cm}$ & 1 cycle & 1.4 & 0.5 & DOD \\
\hline 5 & 59 & Clear cell & Exploratory laparotomy & Pleural effusion & $>1000 \mathrm{ml}$ & $>5 \mathrm{~cm}$ & 2 cycles & 1.5 & 0.25 & DOD \\
\hline 6 & 61 & Clear cell & DS & Bone & $>1000 \mathrm{ml}$ & $<1 \mathrm{~cm}$ & None & 1.6 & - & DOD \\
\hline 7 & 63 & Endometrioid & DS & Liver & $<100 \mathrm{ml}$ & $>5 \mathrm{~cm}$ & 1 cycle & 2.4 & 1.2 & DOD \\
\hline 8 & 51 & Clear cell & Salpingo-oophorectomy & Liver & $100-500 \mathrm{ml}$ & $2-5 \mathrm{~cm}$ & 1 cycle & 2.4 & 1.4 & DOD \\
\hline 9 & 37 & Mucinous & Exploratory laparotomy & Pancreas & $<100 \mathrm{ml}$ & $>5 \mathrm{~cm}$ & 1 cycle & 2.5 & 1.6 & DOD \\
\hline 10 & 63 & Serous & DS & Pleural effusion & $100-500 \mathrm{ml}$ & $1-2 \mathrm{~cm}$ & 2 cycles & 2.5 & 0.5 & DOD \\
\hline 11 & 58 & Mucinous & Salpingo-oophorectomy & $\begin{array}{l}\text { Liver } \\
\text { Spleen }\end{array}$ & $100-500 \mathrm{ml}$ & $>5 \mathrm{~cm}$ & 2 cycles & 2.5 & 0.6 & DOD \\
\hline 12 & 53 & Serous & DS & Liver & $>1000 \mathrm{ml}$ & $>5 \mathrm{~cm}$ & 2 cycles & 2.7 & 0.8 & DOD \\
\hline 13 & 46 & Mucinous & DS + lymphadenectomy & $\begin{array}{l}\text { Liver } \\
\text { Spleen }\end{array}$ & $<100 \mathrm{ml}$ & $>5 \mathrm{~cm}$ & 2 cycles & 3.1 & 1.0 & DOD \\
\hline 14 & 53 & Undifferentiated & DS + lymphadenectomy & Liver & $100-500 \mathrm{ml}$ & $1-2 \mathrm{~cm}$ & None & 3.1 & - & DOD \\
\hline
\end{tabular}

proportion had non-S/E tumours compared with S/E tumours; 12 of the 14 patients had a non-S/E tumor, accounting for $\sim 20 \%$ of the entire non-S/E group. Furthermore, after the initial chemotherapy, $5(10 \%)$ patients in the non-S/E group died within 1 month, which suggested that there is an association between early death and poor chemosensitivity. Because clear cell tumours and mucinous tumours are less likely to respond to NAC than serous tumours, extended surgery should be considered as a first-line therapy for these tumor types.

However, our data indicated the possibility of long-term survival for some patients in the non-S/E group that had poor prognosis. The prognostic factors associated with these cases were residual tumor size, metastatic site, and TP chemotherapy. No research has analysed the prognostic factors in patients with only clear cell or mucinous tumours. Generally, for all stage IV EOC tumours, residual tumor size, PS, and completeness of the surgery are considered the most important prognostic factors that affect OS. Because the purpose of radical cytoreductive surgery is to retain as little gross tumor as possible, optimal surgery is the most important prognostic factor (Bristow et al, 2002; Winter et al, 2008; Vergote et al, 2010; Rauh-Hain et al, 2012). However, previous reports have differed in their definitions of optimal surgery depending on the amount of residual tumor. The median OS has been reported to be 34-64 months in patients with no residual tumours (Winter et al, 2008; Wimberger et al, 2010; Trope et al, 2012), 38 months for those with $<1 \mathrm{~cm}$ residual tumor (Bristow et al, 1999; Elstrand et al, 2012), and 25-40 months for those with $<2 \mathrm{~cm}$ residual tumor (Liu et al, 1997; Akahira et al, 2001; Munkarah et al, 1997). In particular, some reports have shown a longer median OS of approximately 60 months for patients with no residual tumor (Winter et al, 2008; Wimberger et al, 2010). There are two possible reasons for this result: first, many of the enroled patients might have had preferable conditions, such as good PS, because of the prospective study design for cytoreductive surgery in Stage IV EOC; second, the population included many patients with chemosensitive tumours rather than clear cell or mucinous tumours. Our study also demonstrated a favourable prognosis for no residual tumor in both S/E (median OS, 49.2 months) and non$\mathrm{S} / \mathrm{E}$ groups (median OS, 55.2 months). In the non-S/E group, a good prognosis was also associated with resection of metastatic sites (Yes vs No: 2.6 vs 0.8 years, $P=0.258$ ). Furthermore, a favourable prognosis was also associated with metastasis to other single organ, such as the lung, spleen, or navel, especially, the OS rate was higher in patients with both factors; other single organ and no residual tumor (Figure 1A). These data suggest that complete cytoreductive surgery improves the prognosis of patients with resectable metastases, even if they have stage IV EOC. Previous studies of liver resection or diaphragm resection support these results (Bristow et al, 1999; Chereau et al, 2009). In a metaanalysis of patients with stage III or IV ovarian carcinoma, Bristow et al (2002) determined that maximal cytoreduction was one of the most powerful determinants of cohort survival. This group also found that consistent referral of patients with advanced ovarian cancer to expert centres for primary surgery may be the best currently available means for improving OS. In addition, there was no significant difference in pleural effusion between patients with residual tumor and without residual tumor in S/E group (Figure 1B). The possible reasons include that patients with pleural effusion had a high rate of IDS (67\%) or a low rate of $>2 \mathrm{~cm}$ residual tumor (13\%) in the S/E group.

On the basis of the results of a large, randomized, phase III trial, paclitaxel-platinum therapy has been recommended as a first-line regimen for patients with advanced EOC (McGuire et al, 1996). In particular, incorporating paclitaxel into first-line therapy improves the duration of progression-free survival and OS in women with incompletely resected stage III and stage IV ovarian cancer. In the present study, although there were no significant differences in OS between TP chemotherapy and other platinum-based regimens in the S/E group, the OS rate for the non-S/E group was higher for TP chemotherapy than for other platinum-based regimens. The mean cycle number of first-line TP chemotherapy was significantly higher than that of other platinum-based regimens, and good 
compliance with the continuation of TP therapy likely improves this prognosis. Despite good compliance, however, the survival of patients in the non-S/E group with TP chemotherapy was very poor compared with that of the S/E group. Our previous study of patients with recurrent ovarian cancer demonstrated that the prognosis of patients with non-clear cell/mucinous tumours was improved with TP chemotherapy (Kajiyama et al, 2014). The lack of a significant difference in survival according to type of chemotherapy in the S/E group may reflect the OS analysis rather than recurrence-free survival; these patients might have displayed different responses to treatment after initial chemotherapy in terms of recurrence.

Although the advantages of NAC-IDS have been discussed at length in studies comparing this treatment with PDS, PDS still remains the standard therapy for advanced EOC. Many authors have reported that NAC-IDS is associated with lower perioperative morbidity, a higher percentage of complete surgery without residual tumor, and similar survival (Hou et al, 2007; Vergote et al, 2010; Rauh-Hain et al, 2012). In our data, there was also no difference in survival between PDS and IDS (Table 3); however, the rate of early death or treatment-related mortality was much higher among patients who underwent PDS compared with IDS.

Our study has several limitations. Our results were obtained by retrospective analysis, and no details for older cases were available. All patients underwent surgery and pathological diagnosis, and patients who had received only chemotherapy were omitted. Although our patient population with clear cell or mucinous tumours was larger than those of previous studies, even larger studies are necessary because of the variable clinico-pathological characteristics of stage IV EOC patients. Although patients with stage IV EOC can expect long-term survival with active treatment, the general condition of these patients may be exacerbated by the treatment. Therefore, determining the proper treatment for stage IV patients with poor prognosis and poor PS is difficult, and those patients require adequate explanation of the available information to select the proper therapy.

\section{CONCLUSION}

In stage IV EOC, non-S/E tumours were associated with a significantly worse prognosis and higher rates of early mortality compared with S/E tumours. However, our data suggest that complete cytoreductive surgery improves the prognosis of patients with resectable metastases, not only for S/E tumours but also for non-S/E tumours. Therefore, the benefits and risks of aggressive surgery or palliative therapy in therapeutic management must be considered, and the development of new treatment strategies for these patients is required.

\section{ACKNOWLEDGEMENTS}

We sincerely thank Drs Y Kinoshita (Ogaki Municipal Hospital), K Sakakibara (Okazaki Municipal Hospital), A Takeda (Gifu Prefectural Tajimi Hospital), N Kamiya (Nagoya Memorial Hospital), K Matsuzawa (Anjyo Kosei Hospital), T Nakanishi (Aichi cancer center), and S Yamamuro (Nagoya Second Red Cross Hospital) for collaborating with data collection.

\section{CONFLICT OF INTEREST}

The authors state no conflict of interest.

\section{REFERENCES}

Classification and staging of malignant tumours in the female pelvis (1971) Acta Obstet Gynecol Scand 50(1): 1-7.

Akahira JI, Yoshikawa H, Shimizu Y, Tsunematsu R, Hirakawa T, Kuramoto H, Shiromizu K, Kuzuya K, Kamura T, Kikuchi Y, Kodama S, Yamamoto K, Sato S (2001) Prognostic factors of stage IV epithelial ovarian cancer: a multicenter retrospective study. Gynecol Oncol 81(3): 398-403.

Baak JP, Wisse-Brekelmans EC, Langley FA, Talerman A, Delemarre JF (1986) Morphometric data to FIGO stage and histological type and grade for prognosis of ovarian tumours. J Clin Pathol 39(12): 1340-1346.

Bamias A, Psaltopoulou T, Sotiropoulou M, Haidopoulos D, Lianos E, Bournakis E, Papadimitriou C, Rodolakis A, Vlahos G, Dimopoulos MA (2010) Mucinous but not clear cell histology is associated with inferior survival in patients with advanced stage ovarian carcinoma treated with platinum-paclitaxel chemotherapy. Cancer 116(6): 1462-1468.

Bristow RE, Montz FJ, Lagasse LD, Leuchter RS, Karlan BY (1999) Survival impact of surgical cytoreduction in stage IV epithelial ovarian cancer. Gynecol Oncol 72(3): 278-287.

Bristow RE, Tomacruz RS, Armstrong DK, Trimble EL, Montz FJ (2002) Survival effect of maximal cytoreductive surgery for advanced ovarian carcinoma during the platinum era: a meta-analysis. J Clin Oncol 20(5): 1248-1259.

Brun JL, Feyler A, Chene G, Saurel J, Brun G, Hocke C (2000) Long-term results and prognostic factors in patients with epithelial ovarian cancer. Gynecol Oncol 78(1): 21-27.

Chan JK, Teoh D, Hu JM, Shin JY, Osann K, Kapp DS (2008) Do clear cell ovarian carcinomas have poorer prognosis compared to other epithelial cell types? A study of 1411 clear cell ovarian cancers. Gynecol Oncol 109(3): 370-376.

Chereau E, Ballester M, Selle F, Cortez A, Pomel C, Darai E, Rouzier R (2009) Pulmonary morbidity of diaphragmatic surgery for stage III/IV ovarian cancer. BJOG 116(8): 1062-1068.

Crawford SC, Vasey PA, Paul J, Hay A, Davis JA, Kaye SB (2005) Does aggressive surgery only benefit patients with less advanced ovarian cancer? Results from an international comparison within the SCOTROC-1 Trial. J Clin Oncol 23(34): 8802-8811.

Curtin JP, Malik R, Venkatraman ES, Barakat RR, Hoskins WJ (1997) Stage IV ovarian cancer: impact of surgical debulking. Gynecol Oncol 64(1): 9-12.

Elstrand MB, Sandstad B, Oksefjell H, Davidson B, Trope CG (2012) Prognostic significance of residual tumor in patients with epithelial ovarian carcinoma stage IV in a 20 year perspective. Acta Obstet Gynecol Scand 91(3): 308-317.

Goodman HM, Harlow BL, Sheets EE, Muto MG, Brooks S, Steller M, Knapp RC, Berkowitz RS (1992) The role of cytoreductive surgery in the management of stage IV epithelial ovarian carcinoma. Gynecol Oncol 46(3): 367-371.

Hess V, A'Hern R, Nasiri N, King DM, Blake PR, Barton DP, Shepherd JH, Ind T, Bridges J, Harrington K, Kaye SB, Gore ME (2004) Mucinous epithelial ovarian cancer: a separate entity requiring specific treatment. J Clin Oncol 22(6): 1040-1044.

Hou JY, Kelly MG, Yu H, McAlpine JN, Azodi M, Rutherford TJ, Schwartz PE (2007) Neoadjuvant chemotherapy lessens surgical morbidity in advanced ovarian cancer and leads to improved survival in stage IV disease. Gynecol Oncol 105(1): 211-217.

Jemal A, Siegel R, Ward E, Murray T, Xu J, Thun MJ (2007) Cancer statistics, 2007. CA 57(1): 43-66.

Kajiyama H, Shibata K, Mizuno M, Umezu T, Suzuki S, Sekiya R, Niimi K, Mitsui H, Yamamoto E, Kawai M, Nagasaka T, Kikkawa F (2014) Survival benefit of taxane plus platinum in recurrent ovarian cancer with non-clear cell, non-mucinous histology. Journal Gynecol Oncol 25(1): 43-50.

Liu PC, Benjamin I, Morgan MA, King SA, Mikuta JJ, Rubin SC (1997) Effect of surgical debulking on survival in stage IV ovarian cancer. Gynecol Oncol 64(1): 4-8.

Luyckx M, Leblanc E, Filleron T, Morice P, Darai E, Classe JM, Ferron G, Stoeckle E, Pomel C, Vinet B, Chereau E, Bergzoll C, Querleu D (2012) Maximal cytoreduction in patients with FIGO stage IIIC to stage IV ovarian, fallopian, and peritoneal cancer in day-to-day practice: a retrospective french multicentric study. Int J Gynecol Cancer 22(8): 1337-1343.

McGuire WP, Hoskins WJ, Brady MF, Kucera PR, Partridge EE, Look KY, Clarke-Pearson DL, Davidson M (1996) Cyclophosphamide and cisplatin compared with paclitaxel and cisplatin in patients with stage III and stage IV ovarian cancer. $N$ Engl J Med 334(1): 1-6. 
Mizuno M, Kikkawa F, Shibata K, Kajiyama H, Ino K, Kawai M, Nagasaka T, Nomura S (2006) Long-term follow-up and prognostic factor analysis in clear cell adenocarcinoma of the ovary. J Surg Oncol 94(2): 138-143.

Munkarah AR, Hallum 3rd AV, Morris M, Burke TW, Levenback C, Atkinson EN, Wharton JT, Gershenson DM (1997) Prognostic significance of residual disease in patients with stage IV epithelial ovarian cancer. Gynecol Oncol 64(1): 13-17.

Rauh-Hain JA, Rodriguez N, Growdon WB, Goodman AK, Boruta 2nd DM, Horowitz NS, del Carmen MG, Schorge JO (2012) Primary debulking surgery versus neoadjuvant chemotherapy in stage IV ovarian cancer. Ann Surg Oncol 19(3): 959-965.

Sobin LH, Gospodarowicz, Wittekind C (2009) TNM Classification of Malignant Tumours. 7th Edition Wiley-Blackwell: Chichester, UK.

Sugiyama T, Kamura T, Kigawa J, Terakawa N, Kikuchi Y, Kita T, Suzuki M, Sato I, Taguchi K (2000) Clinical characteristics of clear cell carcinoma of the ovary: a distinct histologic type with poor prognosis and resistance to platinum-based chemotherapy. Cancer 88(11): 2584-2589.

Tavassoli FA, Devilee P (2003) Tumours of breast and female genital organs. IARC Press Pathology\&Genetics: Lyon. 117-145.

Trimble E, Valmonte CM, Cheson BD (2000) Clinical trials referral resource. Current clinical trials in epithelial ovarian cancer. Oncology 14(5): 683-684, 687-8 passim.

Trope CG, Elstrand MB, Sandstad B, Davidson B, Oksefjell H (2012) Neoadjuvant chemotherapy, interval debulking surgery or primary surgery in ovarian carcinoma FIGO stage IV? Eur J Cancer 48(14): 2146-2154.
Vergote I, Trope CG, Amant F, Kristensen GB, Ehlen T, Johnson N, Verheijen RH, van der Burg ME, Lacave AJ, Panici PB, Kenter GG, Casado A, Mendiola C, Coens C, Verleye L, Stuart GC, Pecorelli S, Reed NS. European Organisation for RTreatment of CancerGynaecological Cancer GGroup NCT (2010) Neoadjuvant chemotherapy or primary surgery in stage IIIC or IV ovarian cancer. $N$ Engl J Med 363(10): 943-953.

Wimberger P, Wehling M, Lehmann N, Kimmig R, Schmalfeldt B, Burges A, Harter P, Pfisterer J, du Bois A (2010) Influence of residual tumor on outcome in ovarian cancer patients with FIGO stage IV disease: an exploratory analysis of the AGO-OVAR (Arbeitsgemeinschaft Gynaekologische Onkologie Ovarian Cancer Study Group). Ann Surg Oncol 17(6): 1642-1648.

Winter 3rd WE, Maxwell GL, Tian C, Sundborg MJ, Rose GS, Rose PG, Rubin SC, Muggia F, McGuire WP (2008) Tumor residual after surgical cytoreduction in prediction of clinical outcome in stage IV epithelial ovarian cancer: a Gynecologic Oncology Group Study. J Clin Oncol 26(1): 83-89.

This work is published under the standard license to publish agreement. After 12 months the work will become freely available and the license terms will switch to a Creative Commons AttributionNonCommercial-Share Alike 4.0 Unported License.

Supplementary Information accompanies this paper on British Journal of Cancer website (http://www.nature.com/bjc) 